\title{
DISKRESI ANGGOTA Kepolisian NEGARA REPUBLIK INDONESIA DALAM PENANGANAN AKSI UNJUK RASA DAN IMPLIKASINYA TERHADAP KETAHANAN WILAYAH (Studi Di Kepolisian Resort Kota Yogyakarta)
}

\author{
Legowo Saputro \\ Polda DIY \\ Email: mobrig05@yahoo.com
}

\begin{abstract}
This research aimed to, firstly, determining the application of Police Officers discretion on handling of protest action, related forms of action and consideration, constraints and secondly, implications aginst the regional resilience.

This research used qualitative descriptive method of search and data collection in the form of opinions or ideas, phenomena, portrait and documents related to Police Officers discretion on handling of protest action. Data obtained by in depth interviews, observation and studied of literature and documents, which were then analyzed and put in the form of words and portrait that gave an obvious illustration of the object of research. Research was conducted at the Police Resort of Yogyakarta City by taking samples of some Police Officers of Yogyakarta City and Police Department of Yogyakarta, protesters, public, and legal advisor.

The Discretion applied by the Police Officers of Yogyakarta City on handling of protest action that formed of tolerance for violations of protesters in terms of notification and implementation of the protest action, and the action as well as a waiver of any provision in the handling of demonstrations by the police. The constraints that formed in limited and superficially understanding of the discretion by the police, the sanctions provided were personaly, negative responses from the public and the protesters. The discretion of the Police Officers of Yogyakarta City in handling of protest action effected: Firstly, positive effect that created stability of the region of Yogyakarta City and had impact on regional resilience on aspects of ideological, political, social, cultural and security; Secondly, negative consequences in the form of public perception that the violation by protesters was the right thing, when discretion were applied was not well understood by the police. Existing obstacles must be overcame to provide sufficient understanding and knowledge of police discretion, especially to the Police Department of Yogyakarta City, and to the public and protesters.
\end{abstract}

Keywords: Police Discretion, Protest Action, The Regional Resilience.

\begin{abstract}
ABSTRAK
Penelitian ini bertujuan untuk: Pertama, mengetahui penerapan diskresi anggota kepolisian dalam penanganan aksi unjuk rasa, terkait bentuk tindakan dan pertimbangannya serta kendala; dan Kedua, implikasinya terhadap ketahanan wilayah.

Penelitian ini menggunakan metode deskriptif kualitatif yaitu pencarian dan pengumpulan data yang berupa pendapat atau gagasan, fenomena, gambar serta dokumen yang berkaitan dengan diskresi anggota kepolisian dalam penanganan aksi unjuk rasa. Data diperoleh dengan wawancara mendalam, pengamatan serta studi kepustakaan dan dokumen, yang selanjutnya dianalisis dan dituangkan dalam bentuk kata-kata dan gambar sehingga memberikan
\end{abstract}


gambaran yang jelas tentang obyek penelitian. Penelitian dilakukan di Kepolisian Resort Kota Yogyakarta dengan mengambil sampel beberapa Anggota Polresta Yogyakarta dan Polda DIY, pengunjuk rasa, masyarakat,dan ahli hukum.

Diskresi yang diterapkan oleh Anggota Kepolisian Resort Kota Yogyakarta dalam penanganan aksi unjuk rasa berupa toleransi atas pelanggaran pengunjuk rasa dalam hal surat pemberitahuan dan pelaksanaan aksi unjuk rasa, dan tindakan tersebut sekaligus merupakan pengabaian ketentuan dalam penanganan aksi unjuk rasa oleh Polisi. Kendalanya berupa pemahaman yang sempit serta dangkal terhadap diskresi oleh Polisi, sanksi yang diberikan bersifat personal, tanggapan negatif dari masyarakat dan pengunjuk rasa. Diskresi Anggota Kepolisian Resort Kota Yogyakarta dalam penanganan aksi unjuk rasa berakibat, yaitu: Pertama, akibat positif berupa terciptanya stabilitas wilayah di Kota Yogyakarta dan berdampak terhadap ketahanan wilayah pada aspek ideologi, politik, sosial budaya dan keamanan; Kedua yaitu, akibat negatif berupa anggapan masyarakat bahwa pelanggaran yang dilakukan oleh pengunjuk rasa merupakan hal yang benar, apabila diskresi yang diterapkan tidak dipahami dengan baik oleh Polisi. Kendala yang ada harus diatasi dengan memberikan pemahaman dan pengetahuan yang cukup tentang diskresi kepolisian, khususnya kepada Anggota Kepolisian Resort Kota Yogyakarta, dan kepada masyarakat maupun pengunjuk rasa.

\section{Kata kunci: Diskresi Anggota Kepolisian, Unjuk Rasa, Ketahanan Wilayah.}

\section{PENGANTAR}

Hukum pidana merupakan sistem yang dibangun oleh negara untuk melindungi masyarakat dalam kehidupan yang damai, aman dan tertib atas segala gangguan dari pelaku pelanggar norma. Dalam usaha menegakkan hukum pidana tersebut agar dipatuhi oleh masyarakat, berdasarkan undangundang negara menugaskan Polisi untuk usaha tersebut. Polisilah yang mempunyai kekuasaan sangat besar dalam hal penegakkan hukum. Untuk menjalankan kekuasaan yang besar tersebut, Polri diberikan kewenangan, salah satunya terdapat dalam Pasal 5 Ayat (1) Huruf a Angka 4, Pasal 7 Ayat (1) Huruf j, dan Pasal 16 Ayat (1) Undang-undang Nomor 2 Tahun 2002 tentang Kepolisian Negara Republik Indonesia, “...Untuk kepentingan umum, pejabat Kepolisian Negara Republik Indonesia dalam melaksanakan tugas dan wewenangnya dapat bertindak menurut penilaiannya sendiri...”, atau biasa disebut dengan “diskresi”. Diskresi diartikan sebagai kebebasan mengambil keputusan dalam setiap situasi yang dihadapi menurut pendapat sendiri (Simorangkir dkk, 1980:45), sedangkan menurut Aaron (1960:ix), bahwa diskresi merupakan suatu kekuasaan atau wewenang yang dilakukan berdasarkan hukum atas pertimbangan dan keyakinan serta lebih menekankan pertimbangan moral dari pada pertimbangan hukum, selain itu diskresi yang dilakukan oleh Polisi juga dipengaruhi oleh kondisi lingkungan, masyarakat, kepentingan, dan situasi politik. Menurut Faal (1991:144145) bahwa peranan diskresi kepolisian untuk menyatukan tugas pokok yang diemban oleh Polisi yaitu sebagai penjaga keamanan dan ketertiban masyarakat yang dalam pencapaiannya direalisasikan dalam tugas preventif dan tugas represif. Kedua tugas tersebut harus selalu menyatu dalam diri seorang Polisi, ia menindak pelanggar hukum sekaligus membina masyarakat, sebagai penegak hukum sekaligus pembina masyarakat. Kedua tugas tersebut kadang selaras, namun sering juga bertentangan. Di situlah peranan diskresi tersebut. Polisi harus dapat dengan bijaksana menentukan alternatif tindakan apa yang harus dilakukan, yang paling tepat dan paling ia yakini kemanfaatannya, baik dari segi hukum, korban, pelaku, dan masyarakat.

Ridwan (2014:5) dalam "Diskresi dan Tanggung Jawab Pemerintah” menyebutkan 
Legowo Saputro -- Diskresi Anggota Kepolisian Negara Republik Indonesia Dalam Penanganan Aksi Unjuk Rasa Dan Implikasinya Terhadap Ketahanan Wilayah

(Studi Di Kepolisian Resort Kota Yogyakarta)

bahwa, pemberian kewenangan diskresi atau dikenal juga dengan freis ermessen, yaitu kemerdekaan pemerintah untuk dapat bertindak atas inisiatif sendiri dalam menyelesaikan persoalan-persoalan sosial, didasarkan kepada konsepsi negara hukum modern seperti yang dianut oleh Indonesia telah menimbulkan dilema yang penuh kontradiksi, sebab bagi suatu negara hukum modern, setiap tindakan pemerintahannya harus berdasarkan atas hukum atau setidaktidaknya tidak boleh bertentangan dengan hukum, baik hukum tertulis maupun hukum tidak tertulis, sedangkan bersamaan dengan itu kepada pemerintah diserahi pula peran, tugas, dan tanggung jawab yang semakin luas serta berat. Artinya acapkali terjadi kesenjangan antara asas legalitas dengan realitas yang dihadapi pemerintah. Kemerdekaan atau kebebasan pemerintah tersebut mencakup kebebasan interpretasi, kebebasan mempertimbangkan, dan kebebasan mengambil kebijakan (Ridwan, 2014:16).

Dasar hukum pelaksanaan diskresi oleh kepolisian bersumber pada Pembukaan Undang-undang Dasar Negara Republik Indonesia 1945 alenia ke empat, yurisprudensi, Undang-undang Nomor 2 Tahun 2002 tentang Kepolisian Negara Republik Indonesia Pasal 18 Ayat (1), dan Undang-undang Nomor 8 Tahun 1981 tentang KUHAP Pasal 5 Ayat (1) Huruf a Angka 4 dan Pasal 7 Ayat 1 Huruf j, yang secara garis besar menyatakan bahwa, “Demi kepentingan umum, setiap Pejabat Kepolisian Negara Republik Indonesia dalam melaksanakan tugas dan wewenangnya dapat bertindak menurut penilaiannya sendiri”.

Diskresi dapat diterapkan dalam semua lingkup tugas kepolisian baik dalam tugas represif atau penegakkan hukum maupun preventif atau pencegahan berupa pemeliharaan ketertiban masyarakat termasuk dalam hal penanganan unjuk rasa. Kewenangan diskresi tersebut sangat besar karena hanya berdasar penilaian petugas Polisi dan belum jelas batasannya, sehingga mempunyai kecenderungan terhadap terjadinya penyalahgunaan wewenang. Penelitian tentang diskresi khususnya yang dilakukan oleh Anggota Polri kebanyakan terkait penegakkan hukum, dan hampir tidak ada penelitian tersebut berkaitan dengan pemeliharaan ketertiban umum, padahal dalam lingkup tugasnya, Polri lebih banyak bertugas dalam hal pemeliharaan ketertiban umum, sehingga mempunyai peluang yang lebih besar diterapkannya diskresi dan berpeluang besar pula untuk terjadinya penyalahgunaan wewenang, demikian halnya dalam penanganan unjuk rasa, peluang diterapkannya diskresi tersebut sangat besar dan berbanding lurus dengan kemungkinan terjadinya penyalahgunaan wewenang.

Tujuan penelitian ini untuk mengetahui dan mengkaji penerapan diskresi yang berupa bentuk tindakan, alasan atau pertimbangan, pola, syarat, dan kendala oleh Anggota Kepolisian Resort Kota Yogyakarta dalam penanganan aksi unjuk rasa di Kota Yogyakarta, serta untuk mengetahui implikasi dari penerapan diskresi oleh Anggota Kepolisian Resort Kota Yogyakarta dalam penanganan aksi unjuk rasa terhadap ketahanan wilayah (Sunardi, 2004).

\section{PEMBAHASAN}

Diskresi Anggota Kepolisian Resort Kota Yogyakarta dalam Penanganan Aksi Unjuk Rasa

Ketentuan Pasal 10 Ayat (1) dan Ayat (3) Undang-undang Nomor 9 Tahun 1998 tentang Kemerdekaan Menyampaikan Pendapat di Muka Umum, mewajibkan penyampaian 
Tabel. 1

Data Surat Pemberitahuan Aksi Unjuk Rasa di Kota Yogyakarta

\begin{tabular}{|c|c|c|c|c|c|c|c|c|c|c|c|c|c|c|}
\hline \multirow{2}{*}{ No } & \multirow{2}{*}{ Tahun } & \multicolumn{12}{|c|}{ Bulan } & \multirow{2}{*}{ Jumlah } \\
\hline & & Jan & Feb & Mar & Apr & Mei & Jun & Jul & Agu & Sep & Okt & Nov & Des & \\
\hline 1 & 2011 & 1 & 1 & 3 & 7 & 7 & 2 & 4 & 0 & 2 & 5 & 0 & 4 & 36 \\
\hline 2 & 2012 & 3 & 2 & 5 & 3 & 4 & 3 & 1 & 0 & 1 & 4 & 6 & 4 & 36 \\
\hline 3 & 2013 & 1 & 3 & 5 & 4 & 8 & 1 & 0 & 1 & 0 & 4 & 7 & 3 & 37 \\
\hline 4 & 2014 & 0 & 4 & 2 & 4 & 2 & 3 & 0 & 1 & 7 & 6 & 11 & 0 & 40 \\
\hline Jumlah & & 5 & 10 & 15 & 18 & 21 & 9 & 5 & 2 & 10 & 19 & 24 & 11 & 149 \\
\hline
\end{tabular}

Sumber: Satintelkam Polresta Yogyakarta Tahun 2014.

Tabel. 2

Data Unjuk Rasa di Kota Yogyakarta Tahun 2011-2014

\begin{tabular}{|c|c|c|c|c|c|c|c|c|c|c|c|c|c|c|}
\hline \multirow{2}{*}{ No } & \multirow{2}{*}{ Tahun } & \multicolumn{12}{|c|}{ Bulan } & \multirow{2}{*}{ Tota } \\
\hline & & Jan & Feb & Mar & Apr & Mei & Jun & Jul & Agu & Sep & Okt & Nov & Des & \\
\hline 1 & 2011 & 9 & 9 & 9 & 14 & 21 & 13 & 17 & 5 & 14 & 23 & 10 & 21 & 165 \\
\hline 2 & 2012 & 10 & 7 & 51 & 7 & 16 & 9 & 12 & 7 & 9 & 19 & 11 & 16 & 174 \\
\hline 3 & 2013 & 12 & 12 & 8 & 23 & 24 & 20 & 8 & 9 & 13 & 13 & 17 & 10 & 169 \\
\hline 4 & 2014 & 10 & 9 & 13 & 11 & 15 & 12 & 22 & 7 & 17 & 23 & 24 & 9 & 172 \\
\hline \multicolumn{2}{|c|}{ Jumlah } & 41 & 37 & 81 & 55 & 76 & 54 & 59 & 28 & 53 & 78 & 62 & 56 & 680 \\
\hline
\end{tabular}

Sumber: Sat Intelkam Polresta Yogyakarta Tahun 2014.

pendapat di muka umum, diberitahukan secara tertulis kepada Polri selambat-lambatnya 3x24 jam sebelum kegiatan dimulai. Kenyataannya ketentuan tersebut sulit dipenuhi oleh pengunjuk rasa, sebagaimana tabel 1 dan 2 .

Berdasarkan tabel 1 dapat diketahui jumlah surat pemberitahuan unjuk rasa yang disampaikan kepada Polresta Yogyakarta, sedangkan tabel 2 menjelaskan jumlah kegiatan unjuk rasa yang dilakukan di Kota Yogyakarta. Sesuai data tersebut dapat dijelaskan bahwa surat pemberitahuan aksi unjuk rasa yang masuk di Unit Pelayanan Perijinan Satintelkam Polresta Yogyakarta dalam kurun waktu Tahun 2011-2014 hanya 149 kali atau 22\% saja dari 680 kali aksi unjuk rasa yang dilakukan. Apabila dilihat perbulannya bahkan ada aksi unjuk rasa yang tanpa mengirimkan surat pemberitahuan yaitu di Bulan Agustus Tahun 2011 dan Tahun 2012, Bulan November Tahun 2011, Bulan Juli Tahun 2013 dan Tahun 2014, serta Bulan
Januari dan Desember Tahun 2014.

Selain berdasarkan data di atas, penerapan diskresi berkaitan dengan surat pemberitahuan aksi unjuk rasa disampaikan oleh Wakapolresta Yogyakarta, AKBP Agustinus Supriyanto yang menyatakan bahwa tindakan Polresta Yogyakarta tersebut dilakukan sebagai bentuk penyesuaian terkait model pemberitahuan yang dapat dilakukan selain dengan surat pemberitahuan yakni dengan menggunakan media sosial seperti SMS, BBM ataupun email.

Aiptu Rubiyana, mengatakan bahwa:

"Terkait banyaknya aksi unjuk rasa tanpa disertai surat pemberitahuan tersebut, kelengkapan administrasi pengamanan aksi unjuk rasa juga tidak sesuai ketentuan, misalnya tidak dibuatnya rencana pengamanan dan surat perintah pengamanan yang berfungsi sebagai pertanggungjawaban secara administrasi dalam hal pengamanan suatu kegiatan masyarakat, yang berfungsi juga sebagai 
Legowo Saputro -- Diskresi Anggota Kepolisian Negara Republik Indonesia Dalam Penanganan Aksi Unjuk Rasa Dan Implikasinya Terhadap Ketahanan Wilayah

(Studi Di Kepolisian Resort Kota Yogyakarta)

pemberitahuan kepada anggota Polri tentang pelaksanaan kegiatan masyarakat. Sebagai ganti kelengkapan administrasi tersebut berkaitan dengan fungsinya sebagai pemberitahuan, dibuatlah surat telegram tentang suatu kegiatan unjuk rasa, dari segi kecepatan waktu, surat telegram lebih efektif, namun tidak dapat digunakan sebagai pertanggung jawaban secara administrasi" (Wawancara di Polresta Yogyakarta tanggal 11 Februari 2015).

Arahan pimpinan dalam rangka pengamanan unjuk rasa yang biasanya didahului dengan pelaksanaan apel, demi kecepatan kehadiran Polisi di lapangan, dilakukan dengan menggunakan alat komunikasi HT (Handy Talkie). Arahan yang dilakukan berisikan konsep pengamanan, cara bertindak, penempatan personil, serta larangan dalam pelaksanaan pengamanan aksi unjuk rasa. Ketersediaan HT yang terbatas, mengharuskan Perwira Pengendali (Padal) sebagai pemegang HT, menyampaikan kembali kepada anggota Polri di bawah tanggung jawabnya pada saat tiba di lokasi yang menjadi obyek dari unjuk rasa atau saat perjalanan menuju lokasi unjuk rasa.

Pelaksanaan pengamanan unjuk rasa, personil pengamanan tidak melakukan atau tidak melakukan seluruhnya tindakan yang sesuai Peraturan Kapolri Nomor 16 Tahun 2006 tentang Pedoman Pengendalian Massa (Dalmas). Bagian yang dilaksanakan yaitu kegiatan perekaman jalannya aksi, sedangkan personel Dalmas ditempatkan menjadi satu di area yang agak jauh, namun tetap di satu area dari sasaran aksi unjuk rasa dan tetap memantu perkembangannya, tidak dengan baris bersaf dengan menggunakan tali Dalmas di depan massa aksi. Anggota Pengendali Massa tidak melakukan formasi bersaf dengan tali Dalmas karena dengan tindakan tersebut dianggap sebagai penghalang oleh massa aksi dan justru akan menimbulkan ketegangan.

Polisi yang melakukan pemantauan dalam jarak dekat dengan massa aksi dan sasaran aksi hanya dari personil Intelijen, Padal dan beberapa anggota Dalmas. Selanjutnya himbauan oleh satuan Dalmas ataupun oleh satuan pendukung juga tidak dilakukan, yang dilakukan adalah model komunikasi antara Padal atau penanggung jawab lokasi secara face to face dengan korlap ataupun penanggung jawab aksi saat massa aksi memasuki area gedung. Himbauan dengan pengeras suara justru akan mengganggu orasi yang dilakukan oleh pelaku unjuk rasa dan hal tersebut tentu saja memicu sikap perlawanan dari massa aksi, lain halnya apabila himbauan dilakukan secara simpatik dan pribadi dengan penuh rasa hormat dan menaruh kepercayaan kepada koordinator/penanggung jawab aksi agar yang bersangkutan dapat menghimbau kepada seluruh massa aksi untuk tetap dapat menjaga ketertiban dan keamanan selama berlangsungnya aksi unjuk rasa.

Himbauan dengan cara tersebut dapat menjalin komunikasi yang lebih baik dengan massa aksi, sehingga hubungan yang terjalin bukan hanya pada saat pelaksanaan unjuk rasa, melainkan hubungan secara emosional secara terus menerus. Sebagaimana hal yang disampaikan oleh ketua DPRD DIY, Bapak Yuke yang menyatakan bahwa komunikasi merupakan hal yang paling penting dalam berbagai hal, termasuk dalam hal ini penyelesaian masalah. Menurutnya, dengan komunikasi akan terbuka ruang yang sebelumnya tertutup, dengan berkomunikasi akan tahu apa keinginan dari seseorang, begitu pula dalam unjuk rasa, komunikasi yang 
baik akan menurunkan tingkat ketegangan pada situasi unjuk rasa, mencairkan suasana, yang tadinya berapi-api berubah menjadi komunikatif, komunikasi merupakan awal dari sebuah hubungan, komunikasi yang baik akan melahirkan hubungan yang baik pula, namun hendaknya komunikasi dilakukan setiap saat, tidak hanya saat pelaksanaan aksi unjuk rasa, atau pada saat dibutuhkan saja, kapanpun dan di manapun jalinan komunikasi harus tetap dijaga dengan baik.

Aiptu Bambang Eko Lumaksono, mengatakan bahwa:

"Saat ini, Polisi terutama Padal atau Kanit tidak melakukan yang terbaik dalam pengamanan unjuk rasa. Mereka hanya melaporkan perkembangan situasi, pengamatan dan pengaturan lalu lintas, padahal mereka bisa lebih dari itu, seperti berkomunikasi atau sekedar "ngobrol" dengan peserta aksi unjuk rasa. Menurut Aiptu Bambang, bentuk komunikasi saat unjuk rasa tidak harus tentang unjuk rasa, keamanan, ketertiban, atau himbauan Polisi, tetapi bisa apa saja baik keluarga, kuliah atau hal lainnya. Dengan berkomunikasi seperti tersebut lawan bicara tidak merasa dan tidak seperti layaknya sedang diinterogasi, tetapi layaknya seorang teman, sehingga keakraban, rasa saling menghargai dan saling percaya akan timbul, yang pada akhirnya akan tercipta saling pengertian antara pengunjuk rasa dengan Polisi, sehingga tensi tinggi antara pengunjuk rasa dengan Polisi dan sasaran unjuk rasa dapat berkurang, konflik yang berujung kepada bentrokan fisik dapat terhindarkan" (Wawancara Aiptu Bambang Eko Lumaksono, Pejabat Sementara Kanit Dalmas B Sat Sabhara Polresta Yogyakarta, 6 Januari 2015).

Berdasarkan pengamatan peneliti, personil pengendali massa juga tidak menggunakan atau memakai pakaian, peralatan, dan sarana serta prasarana sesuai prosedur pengendalian massa seperti pakaian Dalmas, tali Dalmas, tameng, dan tongkat Dalmas. Peralatan tersebut juga tidak dipersiapkan di dalam kendaraan pengangkut peralatan di lokasi tempat unjuk rasa dilakukan. Selain itu, tahapan pelaksanaan pengamanan aksi unjuk rasa juga tidak dilakukan sesuai Peraturan Kapolri Nomor 16 Tahun 2006 tentang Pedoman Pengendalian Massa. Personil dalmas cenderung menyesuaikan dengan tindakan yang dilakukan oleh pengunjuk rasa.

Pertimbangan yang dipakai Anggota Polresta Yogyakarta pada penerapan diskresi dalam penanganan aksi unjuk rasa sebagai bentuk Public Order Maintenance yaitu: (1) Kepentingan umum, yakni kepentingan seluruh masyarakat Kota Yogyakarta dalam melaksanakan aktivitasnya, berkaitan dengan pelaksanaan aksi unjuk rasa; (2) Karakter pengunjuk rasa, yakni kebiasaan dalam berperilaku kelompok massa aksi tertentu yang telah ditandai atau berdasarkan analisis intelijen; (3) Isu/tema unjuk rasa. Hal ini berpengaruh terhadap konsep pengamanan yang akan dilaksanakan; (4) Jumlah pengunjuk rasa, yang ditentukan berdasarkan surat pemberitahuan atau perkiraan terkait aliansi yang dibentuk oleh pengunjuk rasa; (5) Jumlah petugas/kekuatan. Hal ini berkaitan dengan penerapan diskresi, semakin besar perbandingan jumlah petugas dengan pengunjuk rasa akan semakin mungkin diskresi diterapkan; (6) Lingkungan, Sarana dan Prasarana. Hal ini terutama berkaitan dengan efek yang ditimbulkan akibat penerapan diskresi khususnya dalam pengalihan arus lalu lintas.

Penerapan diskresi oleh petugas terdapat dalam skema gambar di bawah ini: 
Legowo Saputro -- Diskresi Anggota Kepolisian Negara Republik Indonesia Dalam Penanganan Aksi Unjuk Rasa Dan Implikasinya Terhadap Ketahanan Wilayah

(Studi Di Kepolisian Resort Kota Yogyakarta)

Gambar Skema Hirarki Penerapan Diskresi dalam Penanganan Aksi Unjuk Rasa

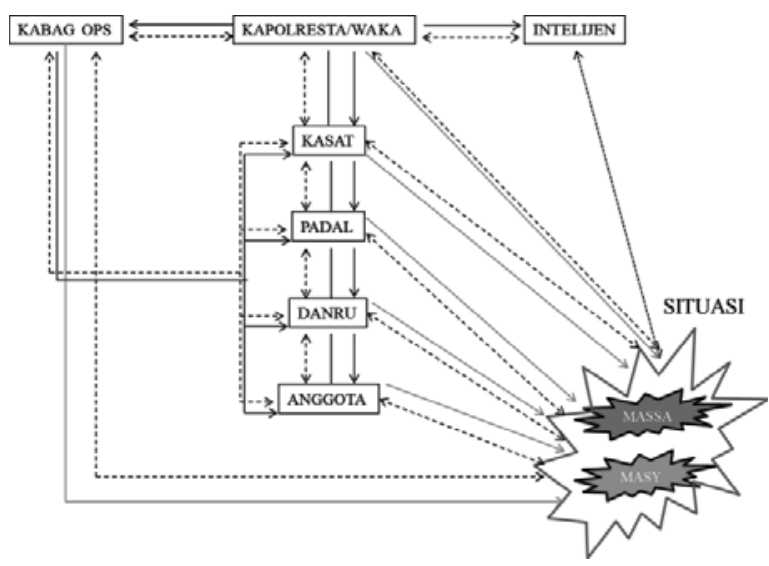

Sumber: Hasil olah data penelitian oleh peneliti 2015.

Gambar tersebut menjelaskan, garis panah hitam merupakan perintah (komando) untuk penerapan diskresi, garis putus-putus merupakan rantai koordinasi ataupun umpan balik. Apabila di dalam kesatuan Polisi disebut sebagai koordinasi yang berarti saran dan masukan antara bawahan dan atasan tentang situasi yang berkembang, sedangkan antara Polisi dan pengunjuk rasa dan masyarakat atau peneliti menyebutnya situasi dapat disebut sebagai koordinasi dan respon timbal balik, situasi yang terjadi bisa langsung direspon oleh Polisi tanpa ada keharusan untuk berkoordinasi dengan pimpinan apabila hal tersebut bersifat mendesak.

Menurut Guru Besar Hukum Pidana Universitas Gadjah Mada Yogyakarta, Prof. Dr. Edward O.S. Hiariej, S.H, M.H., dalam wawancara via email dengan peneliti, menyatakan bahwa:

"Tindakan yang dilakukan oleh Anggota Polresta Yogyakarta seperti hasil penelitian di atas dapat dikategorikan sebagai diskresi dengan tujuan untuk dapat menciptakan suatu keadaan yang kondusif dan mendatangkan manfaat yang lebih besar, dari pada harus melaksanakan aturan sesuai ketentuan terkait penyampaian pendapat di muka umum" (Jabawan Prof Dr. Edward O.S. Hiariej, S.H., M.H., 11 Mei 2015).

Diskresi merupakan tindakan yang dilakukan oleh anggota Polisi berdasarkan penilaiannya sendiri yang bersumber dari pengetahuan yang dimiliki oleh sang Polisi. Peneliti berpendapat bahwa diskresi akan mempunyai hasil yang maksimal apabila Anggota Polisi mempunyai pengetahuan dan pemahaman yang cukup dalam hal: (1) Aturanaturan atau ketentuan yang berlaku. Anggota Polisi wajib mengetahui secara pasti ketentuanketentuan yang berlaku terutama aturan-aturan terkait tantangan yang sering dihadapinya, sehingga yang bersangkutan juga mengetahui aturan mana yang akan dilanggarnya dan aturan yang tetap diikutinya; (2) Situasi lingkungan atau tempat tantangan yang dihadapinya dalam hal ini terkait budaya atau norma yang berlaku. Hukum bukan saja aturan-aturan yang tertulis dan diundangkan saja, tetapi kebiasaan-kebiasaan yang dilakukan masyarakat setempat bisa disebut juga sebagai hukum; (3) Pertimbangan untung atau rugi dalam penerapan diskresi, dalam hal ini yang dimaksud dengan keuntungan atau kerugian adalah bagi kepentingan umum, institusi, dan pribadi Anggota Polisi; (4) Batasan dalam penerapan diskresi, yaitu Anggota Polisi harus menetapkan batasan terkait diskresi yang diterapkan, sampai batasan yang bagaimana diskresi tersebut berlaku dan menyiapkan tindakan lain dalam hal ini tindakan sesuai aturan yang berlaku apabila batasan tersebut telah terlampaui.

\section{Prosedur Penanganan Unjuk Rasa}

Peraturan Kapolri Nomor 7 Tahun 2012 tentang Tata Cara Penyelenggaraan 
Pelayanan, Pengamanan dan Penanganan Perkara Penyampaian Pendapat di Muka Umum adalah sebagai berikut:

Pertama, Penyampaian pemberitahuan kegiatan kepada kepolisian setempat (surat pemberitahuan kegiatan). Maksud dari kepolisian setempat di sini yaitu: (1) Apabila aksi dilaksanakan dalam area yang meliputi dua provinsi atau massa aksi berasal dari beberapa wilayah provinsi, maka pemberitahuan disampaikan kepada Mabes Polri (Bidang Pelayanan Masyarakat Badan Intelijen Keamanan Mabes Polri); (2) Apabila aksi dilaksanakan di beberapa/lintas kabupaten/ kota dan massa aksi berasal dari beberapa kota/ kabupaten maka pemberitahuan disampaikan kepada Kepolisian Daerah (Polda) dalam hal ini adalah Seksi Pelayanan Administrasi Direktorat Intelkam Polda; (3) Apabila aksi dilaksanakan dalam satu lingkup wilayah kabupaten/kota dan massa aksi berasal dari beberapa wilayah kecamatan setempat, maka pemberitahuan disampaikan kepada Kepolisian Resort (Polres/Polresta) dan diterimakan di Satuan Intelijen Keamanan Polres/Polresta; (4) Apabila aksi dilaksanakan dalam lingkup wilayah kecamatan dan massa aksi berasal dari kecamatan dimaksud, maka pemberitahuan disampaikan kepada Polsek setempat (unit pelayanan Polsek).

Kedua, penerimaan surat pemberitahuan oleh Petugas Kepolisian dan dilakukan: (1) Penelitian kebenaran, kelengkapan dan keterangan dalam surat pemberitahuan; (2) Penelitian identitas penanggung jawab aksi (KTP/SIM/Paspor);

Ketiga, Penerbitan STTP (Surat Tanda Terima Pemberitahuan) oleh Kepolisian dengan tembusan satuan Kepolisian terkait dan pemilik/lokasi tempat obyek/sasaran aksi.
Pada tingkat Mabes Polri, STTP ditandatangani oleh Kepala Bidang Pelayanan Masyarakat (Kabid Yanmas) Badan Intelijen Keamanan (Baintelkam) Polri atas nama Kepala Badan Intelijen Keamanan Polri, pada tingkat Provinsi ditandatangani oleh Direktur Intelijen Keamanan atau Wakil Direktur Intelijen Keamanan Polda, pada tingkat kabupaten/kota ditandatangani oleh Kapolres atau Wakapolres atau Kasat Intelkam atas nama Kapolres, dan pada tingkat kecamatan ditandatangani oleh Kapolsek atau Wakapolsek;

Keempat, Koordinasi antara Kepolisian denganpenanggungjawab aksiterkaitpelayanan dan pengamanan aksi demi kelancaran dan ketertiban aksi. Tahapan ini membahas halhal yang akan disepakati antara penanggung jawab aksi dengan pihak kepolisian terkait aksi yang akan dilaksanakan, baik yang sudah terdapat dalam surat pemberitahuan maupun detail pelaksanaan kegiatan aksi yang akan dan seharusnya dilaksanakan, Kepolisian memberikan batasan-batasan, misalnya ketentuan dalam berpawai sehingga pengguna jalan lain tidak terlalu terganggu;

Kelima, Koordinasi dengan pemilik/ pimpinan instansi/lembaga yang menjadi sasaran aksi;

Keenam, Persiapan perangkat pengamanan aksi oleh Kepolisian, dengan tahapan: (1) Pembuatan analisis intelijen oleh Intelijen Keamanan sesuai tingkatannya; (2) Pembuatan rencana pengamanan dan penerbitan surat perintah pengamanan; (3) Rapat koordinasi internal Kepolisian yang membahas cara bertindak di lapangan; (4) Penyiapan sarana dan prasarana dalam kegiatan pengamanan yaitu: peralatan standar pengendalian massa; (5) Pemberian arahan kepada seluruh pasukan pengamanan. 
Legowo Saputro -- Diskresi Anggota Kepolisian Negara Republik Indonesia Dalam Penanganan Aksi Unjuk Rasa Dan Implikasinya Terhadap Ketahanan Wilayah

(Studi Di Kepolisian Resort Kota Yogyakarta)

\section{Unjuk Rasa di Kota Yogyakarta}

Pelaku unjuk rasa di Kota Yogyakarta didominasi oleh mahasiswa. Berdasarkan tabel 3, mahasiswa selalu menjadi unsur yang dominan dalam setiap kegiatan aksi unjuk rasa. Aksi unjuk rasa oleh mahasiswa di Kota Yogyakarta pada Tahun 2011 sebanyak 107 kali atau 65\% dari total 165 kali unjuk rasa yang dilakukan pada tahun tersebut, kemudian di Tahun 2012 sebanyak 92 kali atau 53\% dari 174 total unjuk rasa yang dilakukan, 81 kali atau 48\% di Tahun 2013 dari 169 kali unjuk rasa yang dilakukan, dan 94 kali atau 55\% dari 172 kali unjuk rasa yang dilakukan secara keseluruhan di Tahun 2014. Jika dirataratakan, dalam kurun waktu empat tahun dari Tahun 2011 hingga 2014, mahasiswa melakukan unjuk rasa sebanyak 94 kali atau sekitar 54\% dari rata-rata unjuk rasa yang dilakukan dalam kurun waktu tersebut.

Berdasakan motif atau kepentingannya, unjuk rasa dapat dibedakan menjadi motif ekonomi, politik, sosial budaya, serta hukum dan keamanan, sebagaimana tabel 4.

Berdasarkan data tersebut, terlihat bahwa aksi unjuk rasa atas dasar motif ekonomi dari Tahun 2011-2014 menduduki peringkat tertinggi yaitu 184 kali atau 27,1\% kemudian disusul oleh unjuk rasa bermotifkan sosial budaya sebanyak 181 kali atau 26,6\%, motif politik sebanyak 151 kali atau 22,2\% dan motif lain sebanyak 21 kali atau 3,1\%. Unjuk rasa pada Tahun 2011 terbanyak bermotifkan sosial budaya, saat itu marak unjuk rasa penolakan

Tabel. 3

Data Unjuk Rasa di Kota Yogyakarta Berdasarkan Pelaku

\begin{tabular}{|c|c|c|c|c|c|c|c|c|c|c|c|c|}
\hline \multirow{2}{*}{ No } & Tahun & Mahasiswa & Pelajar & Guru & $\begin{array}{c}\text { Karyawan/B } \\
\text { uruh }\end{array}$ & $\begin{array}{c}\text { LSM/ } \\
\text { Ormas }\end{array}$ & Wartawan & Masy & Parpol & Pedagang & Lainna & Jumlah \\
\hline 1 & 2011 & 107 & 1 & 0 & 6 & 34 & 1 & 13 & 1 & 2 & 1 & 165 \\
\hline 2 & 2012 & 92 & 1 & 0 & 4 & 49 & 2 & 4 & 3 & 6 & 13 & 174 \\
\hline 3 & 2013 & 81 & 1 & 1 & 10 & 48 & 4 & 8 & 3 & 4 & 9 & 169 \\
\hline 4 & 2014 & 94 & 0 & 0 & 7 & 53 & 1 & 6 & 1 & 3 & 7 & 172 \\
\hline Jumlah & $\mathbf{3 7 4}$ & $\mathbf{3}$ & $\mathbf{1}$ & $\mathbf{2 7}$ & $\mathbf{1 8 4}$ & $\mathbf{8}$ & $\mathbf{3 1}$ & $\mathbf{8}$ & $\mathbf{1 5}$ & $\mathbf{3 0}$ & $\mathbf{6 8 0}$ \\
\hline
\end{tabular}

Sumber: Sat Intelkam Polresta Yogyakarta Tahun 2014.

Tabel 4

Data Unjuk Rasa di Kota Yogyakarta Berdasarkan Motif

\begin{tabular}{|c|c|c|c|c|c|c|c|}
\hline \multirow{2}{*}{ No } & \multirow{2}{*}{ Tahun } & \multicolumn{5}{|c|}{ Motif } & \multirow{2}{*}{ Jumlah } \\
\cline { 3 - 8 } & Politik & Ekonomi & Sosbud & $\begin{array}{c}\text { Hukum/Kea } \\
\text { manan }\end{array}$ & Lainnya & \\
\hline 1 & 2011 & 54 & 15 & 56 & 34 & 6 & 165 \\
\hline 2 & 2012 & 18 & 84 & 37 & 31 & 4 & 174 \\
\hline 3 & 2013 & 31 & 50 & 42 & 43 & 3 & 169 \\
\hline 4 & 2014 & 48 & 35 & 46 & 35 & 8 & 172 \\
\hline \multicolumn{2}{|c|}{ Jumah } & $\mathbf{1 5 1}$ & $\mathbf{1 8 4}$ & $\mathbf{1 8 1}$ & $\mathbf{1 4 3}$ & $\mathbf{2 1}$ & 680 \\
\hline
\end{tabular}

Sumber: Sat Intelkam Polresta Yogyakarta Tahun 2014. 
Undang-undang Sistem Pendidikan Nasional, komersialisasi kampus serta aksi solidaritas untuk Timur Tengah. Selanjutnya di tahun yang sama, unjuk rasa bermotif politik juga tidak jauh berbeda jumlahnya dengan motif sosial budaya karena saat itu Kota Yogyakarta dalam suasana pemilihan kepala daerah, serta merupakan titik awal penolakan terhadap RUU Keistimewaan DIY, meskipun telah diwacanakan pada akhir Tahun 2010 yang di dalamnya memuat opsi pemilihan untuk gubernur dan wakil gubernur.

Tahun 2012, unjuk rasa bermotif ekonomi paling banyak dilakukan yaitu 84 kali atau 48\%, dengan 44 kalinya merupakan unjuk rasa menolak kenaikan harga BBM. Saat itu pemerintah berencana untuk menaikkan harga BBM, meskipun rencana tersebut akhirnya batal dilaksanakan. Unjuk rasa bermotif ekonomi menjadi yang terbanyak kembali di Tahun 2013, yaitu di Bulan Juni pemerintah kembali mewacanakan kenaikan harga BBM, dan hal itu benar dilaksanakan oleh pemerintah (BPS, 2013).

\section{Kendala Penerapan Diskresi Dalam Penanganan Aksi Unjuk Rasa}

Pertama, Pemahaman anggota. Diskresi oleh Anggota Polresta Yogyakarta dipahami secara beragam yang disebabkan oleh pengalaman dinas masing-masing anggota Polisi serta pengetahuan yang dimilikinya tentang hukum dan peraturan perundangundangan. Pasal 18 Ayat 1 Undangundang Nomor 2 Tahun 2002 bahwa dalam melaksanakan tugas dan kewenangannya untuk kepentingan umum, Polisi dapat bertindak menurut "penilaiannya sendiri". Frasa "penilaiannya sendiri” tersebut diartikan sebagai kemampuan Anggota Kepolisian
Negara Republik Indonesia, yang selanjutnya disebut sebagai "Polisi”, untuk memahami apa yang sedang terjadi dan aturan-aturan apa saja yang melingkupinya, menganalisisnya serta selanjutnya mewujudkannya dalam bentuk tindakan. Dengan demikian, basis diskresi merupakan penilaian dari individu, tergantung siapa individu tersebut.

Anggota Polisi yang berpangkat bintara dan bertugas pada fungsi operasional akan lebih paham terhadap diskresi dalam tindakannya, dari pada anggota Polisi yang bertugas pada fungsi pembinaan. Anggota Polisi yang lebih lama berdinas/bertugas akan lebih memahami tentang diskresi dari pada Anggota Polisi yang baru beberapa bulan berdinas. Polisi yang bertugas pada fungsi operasional pun memiliki tingkat pemahaman yang berbeda, misalnya Polisi lalu lintas, reskrim, intelijen, dan binmas, tingkat pemahamannya tentang diskresi lebih tinggi atau lebih matang dari pada rekan mereka yang bertugas pada fungsi sabhara.

Tingkat intelektualitas dan pengetahuan anggota Polresta Yogyakarta berbeda-beda, yang disebabkan oleh tingkat pendidikan dan pengalaman yang diperoleh oleh anggota yang bersangkutan. Perbedaan tersebut berpengaruh terhadap tingkat pemahaman terkait diskresi kepolisian dan dengan hal itu berakibat langsung terhadap pelaksanaan tugas di lapangan, terutama bagi anggota yang bertugas pada fungsi operasional, namun demikian tidak jarang pula kewenangan diskresi diambil alih langsung, dalam hal ini dilakukan oleh Kapolresta atau secara hirarki bertindak atas nama Kapolresta dalam bentuk perintah kepada anggota Polisi baik dari fungsi operasional, ataupun pembinaan, baik Polisi lalu lintas, intel, reskrim, binmas ataupun sabhara, untuk penanganan suatu perkara. 
Legowo Saputro -- Diskresi Anggota Kepolisian Negara Republik Indonesia Dalam Penanganan Aksi Unjuk Rasa Dan Implikasinya Terhadap Ketahanan Wilayah

(Studi Di Kepolisian Resort Kota Yogyakarta)

Kedua, Kekuatan Sumber Daya Manusia. Pertimbangan dari penerapan diskresi oleh Anggota Polri adalah demi kepentingan umum dan manfaat yang lebih besar yaitu ketertiban umum. Namun dapat saja, diskresi yang berupa kebijaksanaan dalam bentuk toleransi pada aksi unjuk rasa tersebut tidak diartikan oleh pengunjuk rasa sebagai bentuk penghargaan terhadap kemerdekaan menyampaikan pendapat di muka umum, tetapi sebaliknya sebagai bentuk kelemahan ataupun pembiaran oleh Polisi, sehingga perilaku pengunjuk rasa justru semakin tidak dapat dikendalikan. Hal ini terutama terjadi apabila massa pengunjuk rasa berjumlah besar dan petugas Polisi terlihat lebih sedikit.

Rasio jumlah Polisi dengan penduduk Kota Yogyakarta berdasarkan data di atas yaitu $1: 240$, artinya bahwa satu orang Polisi melayani 240 penduduk, dan hal tersebut sudah sangat “ideal” daripada rasio ideal yang di sampaikan Jenderal Polisi Drs. Sutarman ataupun ketentuan PBB yaitu 1 : 300. Angka rasio tersebut ditentukan sebagai patokan tingkat efektivitas Polisi dalam pelaksanaan tugas melayani masyarakat, semakin kecil perbandingannya, semakin baik tingkat pelayanannya. Namun apabila melihat kembali kenyataan seperti di Polresta Yogyakarta, terkait dengan penyelenggaraan pelayanan, pengamanan dan penanganan unjuk rasa, angka perbandingan tersebut masih jauh dari yang diharapkan (tabel 5).
Menurut peneliti, penghitungan rasio oleh BPS ataupun oleh Polri saat ini menggunakan data jumlah Polri secara keseluruhan pada suatu wilayah dan membandingkannya dengan jumlah penduduk yang beridentitaskan pada wilayah itu. Perhitungan rasio tersebut tidak melihat kondisi riil di lapangan, yaitu jumlah Polisi yang bertugas setiap harinya di lapangan dalam hal ini Polisi yang benar-benar memberikan pelayanan kepada masyarakat. Karena penugasan Polisi menurut fungsinya terbagi menjadi dua, yaitu Polisi pada fungsi pembinaan, yaitu Polisi dengan penugasan administrasi perkantoran, pengawasan, perencanaan dan keuangan, dan sumber daya manusia. Tugas Polisi ini melayani Polisi lain dan bertugas sesuai fungsinya, pada beberapa bidang diawaki oleh PNS Polisi. Selanjutnya fungsi operasional, adalah Polisi yang bertugas melakukan tugas pelayanan kepada masyarakat dalam hal perijinan, penerbitan SKCK, penerbitan SIM, pembinaan masyarakat, pengamanan kegiatan, patroli, penjagaaan dan pengawalan, penyelidikan dan penyidikan perkara pidana. Polisi pada fungsi operasional dalam penugasannya diatur dengan sistem 3 shift/piket dengan lama bertugas 12 jam. Hal inilah yang menurut peneliti di luar dari perhitungan tersebut.

Selanjutnya berkaitan dengan penduduk, BPS atau Polri dalam perhitungan rasio

Tabel 5

Rasio Jumlah Polisi dengan Penduduk Kab/Kota di Provinsi DIY Tahun 2013

\begin{tabular}{clrrrrc}
\hline No & \multicolumn{1}{c}{ Kab/Kota } & Polisi Laki-Laki & Polisi Wanita & Polisi & Penduduk & Rasio \\
\hline 1. & Kulon Progo & 995 & 30 & 1.025 & 401.450 & $1: 385$ \\
2. & Bantul & 1.445 & 70 & 1.515 & 955.015 & $1: 619$ \\
3. & Gunung Kidul & 872 & 19 & 890 & 693.524 & $1: 837$ \\
4. & Sleman & 1.914 & 74 & 1.988 & 1.147 .037 & $1: 577$ \\
5. & Yogyakarta & 1.712 & 60 & 1.772 & 397.828 & $1: 240$ \\
6. & Mapolda DIY & 2.586 & 222 & 2.808 & - & - \\
\hline & Total & 9.524 & 475 & 9.998 & 3.594 .854 & $1: 371$ \\
\hline
\end{tabular}

Sumber: BPS, Statistik Politik dan Keamanan DIY 2013 hal: 10. 
menggunakan jumlah penduduk hasil sensus, seharusnya BPS atau Polri juga memperhitungkan penduduk di luar sensus namun berada pada wilayah itu. Seperti halnya Kota Yogyakarta sebagai Kota Wisata, tentu saja banyak wisatawan yang berada di Kota Yogyakarta setiap harinya. Di samping itu, Kota Yogyakarta juga menjadi tempat bekerjanya orang-orang dari luar kota di wilayah Provinsi DIY maupun Jawa Tengah yang setiap harinya beraktivitas di Kota Yogyakarta (khususnya siang hari). Selain hal tersebut, Kota Yogyakarta disebut sebagai Kota Pelajar, tentu saja banyak pelajar atau mahasiswa yang tinggal menetap di Kota Yogyakarta selama masa studinya. Sesuai data, terdapat 87 asrama mahasiswa yang ada di Kota Yogyakarta dengan jumlah penghuni lebih kurang 1.215 jiwa (BPS, 2013).

Berdasarkan hal tersebut rasio jumlah Polisi dengan jumlah penduduk dapat diperhitungkan sesuai dengan kondisi yang ada pada kenyataannya. Atau dengan rumus sederhana dapat dijabarkan sebagai berikut:

$$
\begin{aligned}
\mathrm{R} & =\mathrm{Py}: \mathrm{P} \\
\mathrm{Py} & =(\mathrm{Po}-(\mathrm{Ps}+\mathrm{Pld}+\mathrm{Pc})) \\
\mathrm{P}= & \mathrm{Psn}+\mathrm{k}+\mathrm{p} / \mathrm{m}+\mathrm{w} \\
\mathrm{R} \quad: & \text { Rasio } \\
\mathrm{Po} \quad: & \text { Jumlah keseluruhan Polisi di suatu } \\
& \text { wilayah } \\
\text { Ps } \quad \text { Jumlah Polisi bertugas pada staf/ } & \text { pembinaan }
\end{aligned}
$$

Pld : Jumlah Polisi yang selesai berdinas dalam satu hari (lepas dinas)

Pc : Jumlah Polisi yang akan bersiap untuk berdinas pada shift berikutnya

Py : Jumah Polisi yang melaksanakan pelayanan

P : Jumlah Riil Penduduk suatu wilayah
Psn : Jumlah Penduduk sesuai sensus

$\mathrm{k}$ : pekerja/karyawan dari luar kota

$\mathrm{p} / \mathrm{m}$ : jumlah pelajar dan mahasiswa dari luar kota

w : jumlah wisatawan

Ketiga, Aturan Pertanggungjawaban Diskresi. Diskresi dalam penanganan aksi unjuk rasa yang diterapkan Anggota Polresta Yogyakarta selama kurun waktu penelitian dan data yang diperoleh, selalu menggunakan pendekatan secara persuasif dan dengan tindakan pencegahan, namun sebenarnya, diskresi Kepolisian tidak selalu dengan model pendekatan tersebut, dapat saja dengan tindakan tegas menggunakan pendekatan kekuatan atau power. Tindakan tegas dengan menggunakan kekuatan tidak dilakukan, karena pertanggungjawaban diskresi sifatnya mengikat secara personal dan hal tersebut menjadi pertimbangan sendiri oleh Anggota Polresta Yogyakarta, yaitu bahwa apabila dalam menggunakan kewenangan tersebut melanggar peraturan perundang-undangan atau melanggar KEPP dan atau ketentuan pidana, maka sanksi akan dijatuhkan secara personal, meskipun tetap saja melalui proses penelitian dalam sidang Komisi KEPP. Sanksi secara personal inilah yang dianggap menakutkan bagi Anggota Polresta Yogyakarta.

Keempat, Masyarakat/Lingkungan. Penerapan diskresi dalam penanganan aksi unjuk rasa yang dilakukan Anggota Polresta Yogyakarta dengan pendekatan persuasif selama ini memang terlihat terlalu lunak, hampir tidak ada tindakan tegas sesuai ketentuan yang diterapkan, hal ini sebagaimana disampaikan tokoh masyarakat, Romo Suhud yang juga ketua Paksi Katon bahwa: 
Legowo Saputro -- Diskresi Anggota Kepolisian Negara Republik Indonesia Dalam Penanganan Aksi Unjuk Rasa Dan Implikasinya Terhadap Ketahanan Wilayah

(Studi Di Kepolisian Resort Kota Yogyakarta)

"Penanganan aksi unjuk rasa yang dilakukan oleh Polresta Yogyakarta selama ini cenderung tidak tegas dan bisa dikatakan terlalu lunak, padahal apabila dilihat, banyak pelanggaran yang dilakukan oleh massa aksi, seperti melakukan pembakaran ban dan membuat macet arus lalu lintas dengan menutup sebagian besar jalan. Menurut Romo Suhud hal tersebut apabila tidak ditindak maka seolah-olah akan menjadi pembenaran oleh massa aksi dalam setiap melakukan aksi unjuk rasa. Pimpinan yang berada di lapangan juga terlihat mendukung tindakan yang selama ini dilakukan dan hal tersebut tergantung dari pimpinannya, sehingga apa yang dilakukan oleh anggota di lapangan menyesuaikan saja perintah pimpinan. Tapi setidaknya, seharusnya setiap anggota Polisi apabila menemukan pelanggaran, paling tidak harus berani menegur dan sebisa mungkin melakukan tindakan tegas. Bekal keberanian ini yang masih kurang dimiliki oleh pimpinan Polresta Yogyakarta maupun seluruh anggota di lapangan" (Wawancara di kediaman Romo Suhud tanggal 11 April 2015).

Kelima, Pengunjuk Rasa. Tindakan pengamanan terhadap unjuk rasa yang dilakukan oleh Anggota Polresta Yogyakarta ditanggapi beragam oleh pengunjuk rasa, ada yang menyatakan bahwa konsep pengamanan unjuk rasa sudah tepat, namun ada pula yang menganggap bahwa konsep pengamanan yang di lakukan oleh Polresta Yogyakarta merupakan bentuk kesengajaan Polisi untuk membenturkan pengunjuk rasa dengan masyarakat. Hal tersebut seperti pernyataan Abdurahman, Mahasiswa Universitas Cokroaminoto, kordum Komite Perjuangan Rakyat Yogyakarta (KPRY), saat melakukan aksi dalam rangka hari HAM sedunia yang menyatakan bahwa Polisi dalam pengamanan aksi justru memprovokasi supaya terjadi benturan dengan masyarakat atau pengguna jalan lain. Menurutnya seharusnya Polisi melakukan pengamanan dengan mengatur lalu lintas, anggapannya, selama ini Polisi seolah-olah memang sengaja membenturkan pengunjuk rasa dengan masyarakat.

\section{Implikasi Diskresi Anggota Kepolisian Resort Kota Yogyakarta dalam Penanganan Aksi Unjuk Rasa terhadap Ketahanan Wilayah}

Diskresi Anggota Kepolisian Resort Kota Yogykarta dalam penanganan aksi unjuk rasa pada dasarnya dipahami sebagai tindakan Anggota Polri untuk melakukan atau tidak melakukan tindakan atau melakukan tindakan lain terhadap pelanggaran yang dilakukan oleh pengunjuk rasa atas ketentuan yang berlaku terkait kemerdekaan menyampaikan pendapat di muka umum. Dalam tindakan diskresi tersebut terdapat unsur yang bisa disebut dengan "mentoleransi” atau lebih kasarnya disebut "membiarkan" pelanggaran tetap terjadi. Hal tersebut apabila berlangsung terus menerus disertai dengan pengabaian terhadap eskalasi pelanggaran yang dilakukan oleh Polisi, maka oleh masyarakat pelanggaran tersebut akan dianggap sebagai hal yang dapat dibenarkan dan dapat dilakukan oleh masyarakat yang lain, meskipun sebenarnya tindakan diskresi tersebut dilakukan sebagai upaya Polresta Yogyakarta dalam rangka melaksanakan tugasnya memelihara keamanan dan ketertiban umum serta sebagai pelindung, pengayom, dan pelayan masyarakat, bukan dimaksudkan sebagai pembiaran terhadap pelanggaran yang terjadi.

Keadaan tersebut apabila berlangsung dalam waktu yang lama akan merubah pandangan masyarakat tentang apa yang sebenarnya tidak boleh dilakukan atau sesuai 
ketentuan disebut sebagai pelanggaran, menjadi hal yang dapat dilakukan dan dianggap benar. Hal tersebut sebagaimana disampaikan AKP Rahmat Yulianto, S.H, M.Si, yang menyatakan bahwa:

"Penanganan aksi unjuk rasa dalam keadaan tertentu, diskresi kepolisian dapat diterapkan, namun diskresi membutuhkan prasyarat atau batasan, sehingga diskresi yang diterapkan tidak berubah atau dianggap sebagai pembiaran, dan apabila keadaan tersebut berlangsung terus-menerus dalam setiap aksi unjuk rasa dan dalam waktu yang lama, maka akan timbul kekaburan terkait ketentuan yang menjadi larangan dalam unjuk rasa yang pada akhirnya akan menjadi bumerang bagi Polisi sendiri berupa pelanggaran yang dilakukan akan terus saja dilakukan dan rendahnya penghormatan masyarakat terhadap ketentuan hukum, serta buruknya citra Polisi dalam penanganan aksi unjuk rasa" (Wawancara di Polda DIY tanggal 6 Januari 2015).

Diskresi Anggota Kepolisian Resort Kota Yogyakarta dalam penanganan aksi unjuk rasa juga berimplikasi positif terhadap ketahanan wilayah dalam lima aspek gatra dinamis sebagai berikut:

Pertama, Aspek Ideologi. Diskresi kepolisian yang diterapkan oleh Anggota Polresta Yogyakarta dalam penanganan aksi unjuk rasa untuk memberi ruang yang cukup terhadap pelaku unjuk rasa dengan berbagai macam tujuan dan latar belakang, meskipun dalam pelaksanaan unjuk rasa tanpa disertai pemberitahuan dan berbagai macam pelanggaran lain dalam batas kewajaran. Tindakannya merupakan wujud kesadaran bahwa perbedaan pandangan merupakan hal yang wajar dan merupakan suatu upaya untuk menjaga agar dinamika kehidupan berdemokrasi dan heterogenitas yang ada di Indonesia tidak mengarah ke dalam perpecahan dan mengancam keutuhan bangsa, selain itu tindakan Polresta Yogyakarta dengan meminimalkan penggunaan peralatan standar pengendalian massa dalam penanganan aksi unjuk rasa yang bertujuan untuk meminimalisir bentrokan dengan pelaku unjuk rasa merupakan penghargaan terhadap nilai kemanusiaan dan penghormatan terhadap HAM dan keadilan.

Diskresi Polisi juga secara tidak langsung berkontribusi dalam memberikan pelajaran tentang toleransi. Penjelasan atas hal tersebut yaitu saat terjadi unjuk rasa yang dalam satu hari lebih dari satu kelompok dan masingmasing kelompok tersebut menolak untuk bergabung meskipun dengan tema yang sama, antar kelompok tersebut saling berkoordinasi dan menunggu untuk bergantian menempati tempat yang diinginkan, mereka tidak saling berebut apalagi berbenturan. Hal tersebut merupakan kontribusi diskresi dalam upaya menjaga nilai-nilai luhur bangsa Indonesia seperti yang terdapat dalam jiwa Pancasila, khususnya dalam hal hormat menghormati dan bertoleransi dalam perbedan yang ada dan memberikan ruang yang cukup agar perbedaan tersebut tersampaikan tanpa ada tekanan ataupun intervensi dari pihak manapun.

Kedua, Aspek Politik. Diskresi dalam penanganan aksi unjuk rasa oleh Polresta Yogyakarta, berdasarkan pengamatan dan analisis peneliti menghasilkan dua wujud dari ketahanan politik wilayah, yaitu pertama hak politik masyarakat dalam hal ini pengunjuk rasa tetap diperolehnya dan yang kedua hubungan antara pemerintah dalam hal ini Polisi dengan masyarakat dan unsur terkait utamanya sasaran aksi unjuk rasa seperti DPRD, Kejaksaan, dan Pemerintahan Daerah 
Legowo Saputro -- Diskresi Anggota Kepolisian Negara Republik Indonesia Dalam Penanganan Aksi Unjuk Rasa Dan Implikasinya Terhadap Ketahanan Wilayah

(Studi Di Kepolisian Resort Kota Yogyakarta)

(Pemkot Yogyakarta) terjalin dengan baik. Koordinasi dan komunikasi yang dilakukan oleh Polisi baik terhadap pengunjuk rasa, masyarakat, Anggota DPRD, walikota dan unsur pemerintahan yang lain merupakan salah satu bentuk diskresi. Komunikasi dan koordinasi yang dilakukan Polisi dengan pengunjuk rasa sebelum pelaksanaan aksi unjuk rasa menjadi tugas Satintelkam Polresta Yogyakarta. Dalam koordinasinya dibahaslah serta disepakati konsep pelaksanaan unjuk rasa dengan tetap mengedepankan ketertiban namun maksud dari unjuk rasa dapat tercapai juga, sehingga informasi serta tuntutan tersampaikan, baik kepada masyarakat maupun sasaran aksi. Selanjutnya, dalam pelaksanaan aksi unjuk rasa terjadi lagi kontak antara Polisi dengan pengunjuk rasa serta masyarakat. Koordinasi kembali dilakukan oleh Polisi dan pengunjuk rasa, dalam koordinasi tersebut dibahas lagi rute, lama unjuk rasa serta himbauan kepada pengunjuk rasa untuk tetap berlaku tertib dan menghormati masyarakat lain.

Ketiga, Aspek Ekonomi. Kegiatan ekonomi pada tingkat wilayah merupakan seluruh kegiatan pemerintah dan masyarakat dalam mengelola wilayah dalam hal faktor produksi yaitu sumber daya alam, tenaga kerja, modal, teknologi, dan manajemen, dan distribusi barang serta jasa untuk kesejahteraan rakyat. Upaya meningkatkan ketahanan ekonomi adalah upaya meningkatkan kapasitas produksi dan kelancaran barang serta jasa secara merata ke seluruh wilayah. Ketahanan ekonomi terkait erat dengan ketahanan wilayah, karena pada dasarnya ketahanan ekonomi merupakan kemampuan masyarakat dalam memenuhi kebutuhannya dan kemampuan tersebut berbanding lurus dengan kesejahteraan masayarakat.
Unjuk rasa berdampak langsung dalam kegiatan ekonomi. Proses distribusi dapat terganggu apabila terjadi pemblokiran jalan, proses produksi terganggu apabila terjadi pemogokan buruh dan unjuk rasa yang disertai pengrusakan dan berakhir menjadi kerusuhan massa yang dapat menghentikan seluruh proses dalam kegiatan ekonomi dan bahkan berakibat kerugian dan kerusakan yang besar. Demikian pula apabila hal tersebut terjadi pada setiap unjuk rasa yang ada di Kota Yogyakarta, akan muncul sentimen negatif dari pelaku pasar dan wisatawan terhadap situasi yang terjadi di Kota Yogyakarta dan hal tersebut akan berdampak kepada nilai investasi di Kota Yogyakarta, penurunan jumlah wisatawan yang berkunjung ke Kota Yogyakarta, sehingga berakibat terhadap menurunnya pendapatan setiap pelaku usaha yang menggantungkan hidupnya pada sektor tersebut, dan yang lebih mengkhawatirkan, apabila situasi tersebut terjadi, dampaknya bukan hanya dialami oleh Kota Yogyakarta tetapi seluruh wilayah di DIY. Upaya yang dilakukan oleh Polresta Yogyakarta dalam penanganan aksi unjuk rasa dengan menerapkan diskresi, secara langsung berdampak pada terciptanya situasi yang kondusif, untuk mencegah tindakan anarkis dan kerusuhan massa.

Keempat, Aspek Sosial Budaya. Sebagai bagian dari masyarakat, hendaknya Polisi menyesuaikan di mana dia bertugas, seperti yang dikatakan Schneider bahwa, "Polisi mencerminkan masyarakat di mana mereka bertugas” (Tabah, 1991). Dalam kaitannya dengan aksi unjuk rasa di Kota Yogyakarta yang kebanyakan dilakukan oleh orang luar Yogyakarta, baik mahasiswa maupun pekerja/ buruh, tetapi mereka melakukannya di Kota Yogyakarta, sehingga sedapat mungkin, 
meskipun berbeda budaya dan adat istiadat, pelaksanaan unjuk rasa dilakukan dengan menghormati dan menghargai budaya Yogyakarta, begitupun dalam penanganannya oleh Polisi. Anggota Polresta Yogyakarta seharusnya wajib memahami budaya Yogyakarta, sehingga dalam pelaksanaan tugas didasari atas pemahamannya terhadap budaya yang tumbuh dan berkembang di Kota Yogyakarta, karena dalam setiap pelaksanaan tugas, Polisi selalu dihadapkan dengan tantangan, dan ketika melakukan intervensi, Polisi umumnya mengedepankan penilaian mereka terhadap situasi (Panggabean dan AliFauzi, 2014:17), yang hal tersebut tergantung bagaimana dan sejauh mana pengetahuan Polisi terhadap situasi (sosial budaya setempat).

Berdasarkan hal tersebut, Polresta Yogyakarta secara tidak langsung juga ikut serta dalam melestarikan budaya dan adat istiadat Yogyakarta serta memberikan kesempatan kepada masyarakat untuk ikut serta dalam usaha tersebut. Penanganan aksi unjuk rasa oleh Polresta Yogyakarta, menjaga dan mempertahankan aktivitas kehidupan dan penghidupan masyarakat Yogyakarta tetap normal, tanpa diliputi rasa takut akan terjadinya reaksi ataupun anarkisme massa yang berujung pada timbulnya korban jiwa maupun harta benda.

Kelima, Aspek Keamanan dan Ketertiban. Aksi unjuk rasa berdampak langsung terhadap situasi keamanan dan ketertiban masyarakat. Seaman-amannya atau setertibnya unjuk rasa pasti berpengaruh terhadap ketertiban umum, paling tidak berpengaruh pada kelancaran arus lalu lintas, begitupun yang terjadi di Kota Yogyakarta. Polresta Yogyakarta sadar bahwa dalam menciptakan keamanan dan ketertiban masyarakat bukan hanya menjadi tugasnya, melainkan di dalamnya terdapat keikutsertaan masyarakat, lingkungan, dan aparatur pemerintah yang lain. Penanganan aksi unjuk rasa oleh Polresta Yogyakarta dengan menerapkan diskresi Kepolisian dalam hal ini adalah dengan bertindak menurut penilaiannya sendiri demi kepentingan umum, melibatkan seluruh elemen masyarakat dan lingkungan sekitarnya. Tujuannya agar masyarakat terbiasa memberikan sikap terhadap aksi unjuk rasa yang terjadi, bukan mengajak untuk menentang atau mendukung aksi unjuk rasa tersebut, melainkan mengajak ikut andil dalam menciptakan situasi yang aman dan tertib serta damai selama unjuk rasa berlangsung.

\section{SIMPULAN}

Tindakan Anggota Kepolisian Resort Kota Yogyakarta dalam penanganan aksi unjuk rasa dapat dikatakan sebagai diskresi yaitu tindakan persuasif dan pencegahan dengan memperbolehkan aksi unjuk rasa tetap berlangsung meskipun tanpa surat pemberitahuan dan pelaksanaannya melakukan pelanggaran. Tindakan tersebut dalam pelaksanaannya menemui kendala terutama terkait sumber daya manusia Polisi berupa rendahnya pemahaman Anggota Polresta Yogyakarta dan berakibat pada kualitas diskresi yang dilakukan, sehingga justru dikatakan sebagai “pembiaran” dan pemahaman tersebut menyebabkan rasa takut untuk bertindak. Efek deterrence diskresi ataupun keberadaan Polisi terhadap pengunjuk rasa tidak terlalu berdampak, bahkan cenderung memicu pengunjuk rasa untuk bertindak dan berperilaku yang mengganggu ketertiban dan kepentingan umum, karena jumlah kekuatan Polisi yang tidak memadai. Masyarakat menganggap penanganan aksi unjuk rasa 
Legowo Saputro -- Diskresi Anggota Kepolisian Negara Republik Indonesia Dalam Penanganan Aksi Unjuk Rasa Dan Implikasinya Terhadap Ketahanan Wilayah

(Studi Di Kepolisian Resort Kota Yogyakarta)

oleh Polresta Yogyakarta terlalu lunak dan memberikan kesan bahwa pelanggaran oleh pelaku unjuk rasa sebagai hal yang benar dan akan diulangi secara terus menerus. Pengunjuk rasa menganggap tindakan diskresi tersebut sebagai kesengajaan yang dilakukan untuk membenturkan pengunjuk rasa dengan masyarakat.

Penanganan aksi unjuk rasa oleh Polresta Yogyakarta berdampak positif terhadap stabilitas wilayah, yaitu tetap terselenggaranya aktivitas berbagai macam aspek kehidupan masyarakat Kota Yogyakarta, hal tersebut apabila dilihat dari sudut pandang tidak terjadinya bentrokan antara Polisi, masyarakat dan pengunjuk rasa. Berdampak negatif pula apabila dilihat dari sudut pandang supremasi hukum, yakni tindakan Anggota Kepolisian Resort Kota Yogyakarta dianggap sebagai lemahnya aparat penegak hukum yaitu Polri atau dalam lingkup wilayah disebut ketidakberdayaan pemerintah dalam mengupayakan tertib dan tegaknya hukum.

Agar diskresi yang diterapkan oleh Anggota Kepolisian Resort Kota Yogyakarta dapat berdampak maksimal bagi ketahanan wilayah, maka terdapat rekomendasi yang diajukan yaitu: (1) Pelatihan dan pendidikan terkait permasalahan dalam pelaksanaan tugas Anggota Polri. Polri perlu membentuk suatu badan khusus untuk penelitian dan pengembangan bagi Institusi Polri, sehingga aturan ataupun ketentuan serta kebijakan yang dikeluarkan oleh Polri lahir dari proses secara ilmiah, sesuai karekteristik wilayah yang berbeda-beda; (2) Penambahan jumlah Anggota Polri yang disesuaikan dengan karakteristik wilayah; (3) Penjelasan tentang diskresi dalam hal ketertiban umum agar dikomunikasikan kepada masyarakat, sehingga tidak timbul persepsi negatif dari masyarakat terkait tindakan yang dilakukan oleh Polisi.

\section{DAFTAR PUSTAKA}

Aaron, Thomas J., 1960. The Control of Police Discretion. Illinois, Charles, C. Thomas, Springfield.

BPS, Statistik Politik dan Keamanan DIY 2013, Badan Pusat Statistik Daerah Istimewa Yogyakarta.

Faal, M., 1991, Penyaringan Perkara Pidana oleh Kepolisian (Discretion Kepolisian). Jakarta: P.T. Paradnya Paramitha.

Panggabean, R., dan Ali-Fauzi, I., 2014. Pemolisian Konflik Keagamaan di Indonesia. Jakarta: PUSAD Paramadina.

Ridwan, 2014. Diskresi dan Tanggung Jawab Pemerintah. Yogyakarta: FH UII Press. Simorangkir, J.C.T., 1980. Kamus Hukum. Jakarta: Aksara Baru.

Sunardi, R.M., 2004, Pembinaan Ketahanan Bangsa Dalam Rangka Memperkokoh Keutuhan Negara Kesatuan Republik Indonesia, Jakarta: P.T. Katernita Adidarma.

Tabah, A. 1991. Menatap Dengan Mata Hati Polisi Indonesia. Jakarta: P.T. Gramedia Pustaka Utama.

\section{Undang-Undang dan Peraturan}

1. UU No. 9 Tahun 1998, Tentang Kemerdekaan Menyampaikan Pendapat Di Muka Umum.

2. UU No. 2 Tahun 2002 Tentang Kepolisian Negara Republik Indonesia.

3. Peraturan Kapolri No. 16 Tahun 2006 Tentang Pedoman Pengendalian Massa.

4. Peraturan Kapolri No. 7 Tahun 2012 Tentang Tata Cara Penyelenggaraan, 
Pelayanan, Pengamanan, Dan Penanganan Perkara Penyampaian Pendapat Di Muka Umum.

\section{Wawancara}

1. Aiptu Bambang Eko Lumaksono, 6 Januari 2015.

2. Aiptu Rubiyana, 11 Februari 2015.

3. Romo Suhud, 11 April 2015.
4. Prof. Dr. Edward O.S. Hiariej, S.H., M.H., 11 Mei 2015.

5. AKP Rahmat Yulianto, S.H., M.Si., 6 Januari 2015.

6. AKBP Agustinus Supriyanto

7. Bapak Yuke, Ketua DPRD DIY

8. Abdurrahman: Mahasiswa Universitas Cokroaminoto. 